\title{
Evaluation of fermented locust bean meal (Parkia biglobosa) as replacement to soybean meal on production performance, blood profile and gut morphology of broiler chicken
}

\author{
Foluke A. Aderemi, Olufemi. M. Alabi, Mathew. O. Ayoola ${ }^{\star}$ and Loveth O. Oyelami \\ Department of Animal Science and Fisheries Management, Bowen University Iwo, Osun state Nigeria, P. M. B 284, \\ Osun state, Nigeria. \\ *Corresponding author. Email: ayoolamatt@gmail.com. Tel: +2348038038406.
}

Copyright (C) 2017 Aderemi et al. This article remains permanently open access under the terms of the Creative Commons Attribution License 4.0, which permits unrestricted use, distribution, and reproduction in any medium, provided the original work is properly cited.

Received 2nd August, 2017; Accepted 12th September, 2017

\begin{abstract}
The high cost of soybean meal, and competition as food between human and animal have necessitated search for alternative plant protein source in poultry diet. Eight weeks trial was carried out on the evaluation of fermented locust bean meal (FLBM) as replacement for soybean meal (SBM) in broiler production. Ninety days old broilers were allotted randomly to three treatment diets, replicated three times with 10 birds per replicate. Diets I (control) did not contain FLBM, diets II and III had 50 and 100\% FLBM inclusions respectively as replacement for soybean meal in both starter and finisher phases. At the end of finisher phase, 4 birds were randomly selected per replicate for analyses of blood samples and evaluation of internal organs and carcass characteristics. At starter phase, body weight was not significantly affected $(P>0.05)$ by treatment diets among experimental groups. The feed intake was lower in diet III, and feed conversion ratio was better in diet I significantly $(\mathrm{P}<0.05)$. Mortality of birds on diet III was higher significantly $(P<0.05)$. At the finisher level, broilers fed diet I had higher weight gain and better feed conversion ratio, which was significantly $(P<0.05)$ similar to diet II. The packed cell volume $(P C V)$, haemoglobin, red blood cell and platelets of birds fed diet II were significantly $(\mathrm{P}<0.05)$ higher when compared to those fed diets I and III and were within normal range for healthy birds. Blood serum showed that glucose, aspartate transaminase, cholesterol and creatinine of birds fed diet III were significantly $(\mathrm{P}<0.05)$ higher than others. Measurement of organs revealed that liver, lungs, intestine, gizzard and heart of those fed diets II and III were significantly $(\mathrm{P}<0.05)$ similar and smaller than the control with no traces of inflammation. Conclusively, FLBM could replace up to 50\% SBM in broiler diet without adverse effect on the production performance.
\end{abstract}

Key words: Broilers, fermented locust bean meal, haematology, production performance, soybean meal.

\section{INTRODUCTION}

The competitive demand for conventional plant protein origin (soybean meal and groundnut cake) has led to a high cost of livestock in Nigeria. Hence, the need for additional protein supplies to promote sustainable monogastric livestock for least cost formulation and production (Ari and Ayanwale, 2012). One of such legumes is Parkia biglobosa, which is commonly known as African locust bean. It is a tropical tree which is native to Africa and widely distributed in the savannah region.

The tree is usually and carefully preserved by inhabitants of the areas where it grows because they are valuable source of reliable food. $P$. biglobosa has high protein and better amino acid profile that recommends its consumption as Daddawa in Hausa and Iru in Yoruba 
(Campbell-Platt, 1980). The seed is consumed in small quantity by human, therefore relinquished the fair of competition with animal as source of useful plant protein ingredients substitute for animal feed (Alabi et al., 2005).

The utilization of locust bean in monogastrics nutrition as replacement for protein source. Groundnut cake was reported to improve production performance, nitrogen retention and feed utilization (Bridget et al., 2004; Alabi et al., 2005). Ayanwale and Ari (2002) and Dawodu (2009) found a positive attribute for fermented as against the unfermented locust bean which was said to inhibit broiler's growth due to less protein quality and essential vitamins (Fetuga et al., 1974). However, Anti-nutritional factors (ANFs) such as tannins, oxalate and hydrogen cyanide had been reported to limit the utilization of locust bean as feed ingredient (Apata, 2003). Fermentation has been reported to detoxify some natural toxins which may occur in beans, improve the nutritive-value, digestibility and growth (Bridget et al., 2004).

However, in previous studies FLBM was used to replace groundnut cake meal (GNC) which is a plant protein source with less protein content as compared to soybean meal. To the best of our knowledge, studies on production performance and carcass characteristics in utilization and replacement of FLBM with soybean meal in broilers diet are scanty. Therefore this study was designed to evaluate the replacement of soybean meal with fermented locust bean meal in broiler's diet with respect to production performance, organ weight, carcass characteristics, serum and hematological blood profile.

\section{MATERIALS AND METHODS}

\section{Location of experiment}

The experiment was conducted at the Teaching and Research Farms of Bowen University Iwo, Osun State, Nigeria. The study area is located in Derived Savanna Agro-Ecological Zone characterized with environmental temperature range of 15 to $28^{\circ} \mathrm{C}$ and mean annual rainfall of $1400 \mathrm{~mm}$.

\section{Preparation of experimental diet}

The Parkia biglobosa seeds were sourced from Bowen University Teaching and Research Farms. The $p$. biglobosa seeds were removed from the pods and washed clean off the pulp as described by Ayanwale and Ari (2002). A fermentation process adapted from Fetugal et al. (1974) and local processing industries in Nigeria was used. The seeds were boiled in water for 12 hours without enzyme or starter culture with large pots in open firewood to soften the seed coats. The seeds were lightly pounded with pestle and mortar to separate the seed
Table 1. Proximate compositions of fermented locust beans.

\begin{tabular}{lc}
\hline Components & Locust beans \\
\hline Dry matter (\%) & 8.4 \\
Crude protein (\%) & 16.56 \\
Ether extract (\%) & 18.8 \\
Crude fibre (\%) & 11.75 \\
Ash (\%) & 4.18 \\
Nitrogen free extract (\%) & 9.31 \\
\hline
\end{tabular}

coats from the seeds. The decorticated seeds were wrapped in a polyethylene bag to allow anaerobic fermentation. The fermentation process lasted for 24 hours until the seeds turn dark brown and softened. The seeds were later oven dried at a temperature of $40^{\circ} \mathrm{C}$ for 3 days, to prevent denaturation of the protein in locust bean meal and then grind into powdery form to produce fermented locust bean meal (FLBM). The proximate composition of FLBM was determined using AOAC (1990) (Table 1). The other ingredients used for formulating the diets were obtained from a reputable feed meal at Iwo.

\section{Experimental procedure and birds' management}

Three test diets were formulated; FLBM was used to replace SBM at two inclusion levels (50\% and $100 \%$ ). All ingredients were supplied and adjusted to make diets isocaloric. The gross composition of the experimental diet of the starter and finisher phase is shown in Table 2. Ninety days old Ross broilers were randomly assigned to three dietary treatments and replicated three times. The experiment lasted 4 and 8 weeks for starter and finisher phase respectively. Fresh feed and water were provided ad libitum daily at 0900 h. Feed supplied and feed leftover were weighed on the same day to calculate the feed intake. Mortalities were recorded daily and each bird was weighed weekly to calculate the body weight gain. Feed conversion ratio and feed efficiency were calculated at the end of each experimental phase. All standard routine management practices, medication and vaccination were strictly observed. Throughout the experiment, chickens were handled according to the principles of animals care in experimentation (NRC, 1985).

\section{Blood collection and analysis}

Blood samples were collected at the 8th week of study from the experimental birds. Blood samples were collected from 4 birds per replicate, through the wing web veno-puncture method with the use of new syringes and needles as described by Tuffery (1995). From each bird, $5 \mathrm{ml}$ of the blood was collected aseptically and deposited in a well labelled EDTA sample bottle for haematological 
Table 2. Gross composition of experimental diets.

\begin{tabular}{lcccccc}
\hline \multirow{2}{*}{ Ingredients } & \multicolumn{3}{c}{ Starter / Diet } & \multicolumn{3}{c}{ Finisher / Diet } \\
\cline { 2 - 7 } & I & II & III & I & II & III \\
\hline Maize & 57.5 & 57.5 & 57.5 & 70.5 & 70.5 & 70.5 \\
Locust beans & - & 3.5 & 7 & - & 3 & 6 \\
Soya bean meal & 7 & 3.5 & - & 6 & 3 & - \\
Wheat offal & 3 & 3 & 3 & 2 & 2 & 2 \\
Fish meal (72\%) & 9 & 9 & 9 & 3 & 3 & 3 \\
palm kernel cake & 3 & 3 & 3 & 3 & 3 & 3 \\
Groundnut cake & 15 & 15 & 15 & 10 & 10 & 10 \\
Bone meal & 3 & 3 & 3 & 3 & 3 & 3 \\
Oyster shell & 2 & 2 & 2 & 2 & 2 & 2 \\
Salt & 0.25 & 0.25 & 0.25 & 0.25 & 0.25 & 0.25 \\
Premix & 0.25 & 0.25 & 0.25 & 0.25 & 0.25 & 0.25 \\
Total (kg) & 100 & 100 & 100 & 100 & 100 & 100 \\
Lysine & 0.1 & 0.1 & 0.1 & 0.1 & 0.1 & 0.1 \\
Methionine & 0.1 & 0.1 & 0.1 & 0.1 & 0.1 & 0.1
\end{tabular}

Calculated composition

\begin{tabular}{lllllll} 
Metabolizable energy $\left(\mathrm{kcal} \mathrm{kg}^{-1}\right)$ & 2900.36 & 2900.66 & 2900.96 & 3010.34 & 3010.24 & 3010.34 \\
Crude protein (\%) & 21.17 & 21.66 & 21.18 & 16.18 & 15.77 & 15.35 \\
Crude fibre (\%) & 3.33 & 3.41 & 3.48 & 3.24 & 3.32 & 3.39 \\
\hline
\end{tabular}

Premix* To provide the following vitamin/mineral composition: Vitamin B, 6,000,000 IU; Vitamin D3, 2000000 IU; Vitamin E, 4000mg; Vitamin K3 , 600 mg; Vitamin B1 , 300mg; Vitamin B2 , 3500 mg; Vitamin B6, 800 mg; Vitamin B12, $40 \mathrm{mg}$; Pantothenate, $1100 \mathrm{mg}$; nicotinic acid, $15000 \mathrm{mg}$; folic acid, $250 \mathrm{mg}$; Biotin, $80 \mathrm{mg}$; Na2SeO3 , 200mg; FeSo4H2O, 85g; ZnSO4H2O, 90g; CuSO4 H2O, 5g; MnSO4 H2O, 85g.

analysis while another $5 \mathrm{ml}$ was deposited in a sterile sample bottle for serum biochemical analysis as described by Tuleun et al. (2009).

\section{Measurement of organs and carcass analysis}

At the end of the experiment, 4 birds per replicate were randomly selected, weighed and sacrificed using electrical stunning before the severance of the jugular vein for proper bleeding. They were defeathered, weighed and dissected to bring out the internal organs. Harvested organs and selected body parts include shank, intestine, head, liver, gizzard, lungs and breast were weighed using a sensitive scale. Measured organs and body parts were expressed as the percentage of the dressed weight.

\section{Statistical analysis}

Data obtained were subjected to one way Analysis of variance (ANOVA) using SAS (2006). Means with significant difference among the treatments were separated using the Duncan's Multiple Range Test of the same software.

\section{RESULTS}

The performance characteristics of broilers fed the experimental diet as shown in Table 3 . The initial body weight and final body weight are not significantly $(P>0.05)$ different for birds at both starter and finisher phase. The total body weight gain was not significant $(P>0.05)$ at starter phase but birds on group I had significantly $(\mathrm{P}<0.05)$ higher value as compare to group II and III at finisher phase. The daily feed intake and total feed intake of birds on group I and II were similar and significantly $(\mathrm{P}<0.05)$ higher than group III at both phases. The feed conversion ratio (FCR) for all the groups in the starter phase differed significantly $(P<0.05)$ with group I the best followed by groups II and III. Whereas in the finisher counterpart, groups I and II were statistically similar $(\mathrm{P}<0.05)$ but different from group III. The mortality rate (\%) for groups I and II were similar and significantly $(\mathrm{P}<0.05)$ lower than group III at starter phase. The result of the blood profile as shown in Table 4, showed that all haematological values were significantly different $(P<0.05)$ between the treated diets. Birds fed diet I and II are statistically similar and had significantly $(P<0.05)$ higher values for packed cell volume (PCV), red blood cell (RBC), haemoglobin $(\mathrm{Hb})$ and platelets as compared 
Table 3. Performance characteristics of broilers fed control and experimental diets for 8 weeks.

\begin{tabular}{lcccccccc}
\hline \multirow{2}{*}{ Parameters } & \multicolumn{3}{c}{ Starter phase } & (1 to 4weeks) & \multicolumn{3}{c}{ Finisher phase (4 to 8weeks) } \\
\cline { 2 - 9 } & I & II & III & SEM & I & II & III & SEM \\
\hline Initial BW (g) & 34.01 & 34.03 & 34.05 & 0.01 & 553.00 & 554.00 & 553.00 & 3.25 \\
Final BW(g) & 553.00 & 554.00 & 553.00 & 3.25 & 2163.11 & 2105.34 & 2078.23 & 21.40 \\
Total BWG (g) & 519.99 & 520.97 & 518.95 & 3.01 & $1610.11^{\mathrm{a}}$ & $1551.34^{\mathrm{ab}}$ & $1525.23^{\mathrm{b}}$ & 15.62 \\
Daily FI (g/week) & $147.59^{\mathrm{a}}$ & $141.35^{\mathrm{a}}$ & $124.13^{\mathrm{b}}$ & 1.01 & $268.20^{\mathrm{a}}$ & $259.09^{\mathrm{a}}$ & $234.81^{\mathrm{b}}$ & 5.26 \\
Total FI (g) & $693.00^{\mathrm{a}}$ & $684.00^{\mathrm{ab}}$ & $623.00^{\mathrm{c}}$ & 3.13 & $1242.31^{\mathrm{a}}$ & $1173.77^{\mathrm{ab}}$ & $1140.81^{\mathrm{c}}$ & 19.44 \\
FCR & $1.14^{\mathrm{c}}$ & $1.32^{\mathrm{b}}$ & $1.96^{\mathrm{a}}$ & 0.25 & $1.18^{\mathrm{bc}}$ & $1.20^{\mathrm{b}}$ & $1.82^{\mathrm{a}}$ & 0.76 \\
Feed efficiency & 0.07 & 0.08 & 0.11 & 0.01 & 0.02 & 0.03 & 0.07 & 0.00 \\
Mortality & $2.00^{\mathrm{bc}}$ & $3.00^{\mathrm{b}}$ & $6.00^{\mathrm{a}}$ & 3.33 & 0.00 & 0.00 & 0.00 & 0.00 \\
\hline
\end{tabular}

${ }^{\mathrm{abc}}$ means within the same row with different superscripts were significantly different $(P<0.05)$.

Table 4. Haematological and serum parameters of the birds fed control and experimental diets.

\begin{tabular}{|c|c|c|c|c|}
\hline Parameters & $\mathbf{I}$ & II & III & SEM \\
\hline \multicolumn{5}{|l|}{ Haematological parameters } \\
\hline Packed cell volume (PCV) (\%) & $24.00^{\mathrm{a}}$ & $24.67^{a}$ & $22.33^{b}$ & 1.03 \\
\hline Heamoglobin (g/d) & $7.30^{\mathrm{ab}}$ & $8.23^{a}$ & $6.97^{c}$ & 0.38 \\
\hline Red blood cell (106ul) & $2.34^{\mathrm{ab}}$ & $2.46^{a}$ & $2.04^{c}$ & 0.20 \\
\hline White blood cell (106ul) & $13.58^{\mathrm{c}}$ & $14.60^{\mathrm{b}}$ & $16.43^{\mathrm{a}}$ & 1.31 \\
\hline Platelet (\%) & $14.33^{\mathrm{b}}$ & $16.70^{\mathrm{a}}$ & $12.70^{\circ}$ & 5.00 \\
\hline \multicolumn{5}{|c|}{ Serum biochemistry parameters } \\
\hline Glucose (mg/dl) & $207.40^{\mathrm{b}}$ & $207.35^{\mathrm{b}}$ & $230.32^{\mathrm{a}}$ & 7.50 \\
\hline Aspartate transaminase (i.u/l) & $124.07^{c}$ & $152.87^{b}$ & $219.88^{a}$ & 16.58 \\
\hline Alanine transaminase (i.u/l) & 10.38 & 9.60 & 10.09 & 1.47 \\
\hline Albumin (mg/dl) & 1.63 & 1.66 & 1.56 & 0.12 \\
\hline Total protein $(\mathrm{mg} / \mathrm{dl})$ & $3.71^{c}$ & $4.28^{a}$ & $3.91^{\mathrm{b}}$ & 0.19 \\
\hline Cholesterol (mg/dl) & $118.40^{\mathrm{b}}$ & $110.37^{c}$ & $122.03^{a}$ & 6.28 \\
\hline Uric acid (mg/dl) & 2.93 & 2.97 & 2.79 & 0.21 \\
\hline Creatinine $(\mathrm{mg})$ & $2.21^{\mathrm{b}}$ & $1.87^{\mathrm{bc}}$ & $4.37^{\mathrm{a}}$ & 0.49 \\
\hline
\end{tabular}

to birds fed diet III. White blood cells (WBC) differed significantly $(\mathrm{P}<0.05)$ for all groups with group III the highest followed by groups II and I. Blood serum showed that the glucose, aspartate transaminase and creatinine of those fed diet III were significantly $(\mathrm{P}<0.05)$ higher than others. Birds fed diet III had highest value for cholesterol $(122 \mathrm{mg} / \mathrm{dl})$ which was significantly $(\mathrm{P}<0.05)$ highest followed by groups I and II. Total protein was with highest value $(4.28 \mathrm{mg} / \mathrm{dl})$ in birds fed diet II which differed significantly $(P<0.05)$ from other dietary treatment. As shown in Table 5, the organ weights of the birds were significantly $(\mathrm{P}<0.05)$ affected by the dietary treatments. The liver, intestine, gizzard and heart of those fed diets I (control) and diet II were statistically similar, while those on diet III were smaller significantly $(\mathrm{P}<0.05)$. Live weight value of birds on the control was superior to all others though not significant $(P>0.05)$. The shank, wing and breast of birds on diet III had the least values significantly $(P<0.05)$ as compared to birds on diet I and II that are statistically similar. Proventiculus and the spleen were similar across the diets and no particular statistical trend was observed. 
Table 5. Carcass and organ weight of experimental birds, calculated as percentage of live weight

\begin{tabular}{lcccc}
\hline Parameters & $\mathrm{I}$ & $\mathrm{II}$ & $\mathrm{III}$ & SEM \\
\hline Live weight (g) & 1.60 & 1.50 & 1.48 & 0.02 \\
Shank (\%) & $17.68^{\mathrm{a}}$ & $17.07^{\mathrm{a}}$ & $11.44^{\mathrm{b}}$ & 0.80 \\
Wing (\%) & $5.47^{\mathrm{ab}}$ & $6.21^{\mathrm{a}}$ & $5.41^{\mathrm{b}}$ & 0.05 \\
Breast (\%) & $10.55^{\mathrm{a}}$ & $10.02^{\mathrm{ab}}$ & $8.93^{\mathrm{c}}$ & 0.05 \\
Heart (\%) & $0.43^{\mathrm{a}}$ & $0.41^{\mathrm{a}}$ & $0.36^{\mathrm{b}}$ & 0.01 \\
Head (\%) & 2.91 & 3.00 & 2.99 & 0.20 \\
Spleen (\%) & 0.09 & 0.09 & 0.08 & 0.001 \\
Proventiculus (\%) & 0.47 & 0.46 & 0.46 & 0.01 \\
Gizzard (\%) & $2.44^{\mathrm{a}}$ & $2.41^{\mathrm{ab}}$ & $2.31^{\mathrm{c}}$ & 0.01 \\
Lung (\%) & $0.40^{\mathrm{a}}$ & $0.40^{\mathrm{a}}$ & $0.27^{\mathrm{b}}$ & 0.001 \\
Liver (\%) & $1.47^{\mathrm{a}}$ & $1.40^{\mathrm{ab}}$ & $1.28^{\mathrm{c}}$ & 0.01 \\
Intestine (\%) & $4.19^{\mathrm{a}}$ & $4.09^{\mathrm{ab}}$ & $3.91^{\mathrm{c}}$ & 0.01 \\
\hline
\end{tabular}

${ }^{a b c}$ means within the same row with different superscripts were significantly different $(P<0.05)$.

\section{DISCUSSION}

The observed increased feed intake of birds in control as shown in Table 3 and compared to low feed intake in FLBM diet can be attributed to the odour of locust bean cum reduced feed acceptability by birds. At the level of inclusion $100 \%$, the smell of the FLBM masked the smell of other ingredients making the diets unattractive and possibly unpalatable to the birds, while at $50 \%$ FLBM inclusion, birds can still tolerate the aroma. This result is similar to the findings of Odunsi (2003) who reported that feed intake by animals' increases if the aroma of their diet is acceptable. However, the better FCR and feed efficiency in diet II was similar to control at finisher phase, and can be attributed to efficiency of nitrogen metabolism by birds for tissue development. This result corrobate the findings of Ari and Ayanwale (2012) that fermented locust bean is characterised with high nitrogen retention which enhance protein utilization in animals. The poor result observed at $100 \%$ FLBM (diet III) can be attributed to poor utilization due to palatability and accumulated effect of some anti-nutritional factors that are not completely detoxify by fermentation. However, FCR and feed efficiency results at starter phase for FLBM diets may be attributed to poor utilization of the plant protein source by the chicks (Aderemi and Alabi, 2013). Mortality recorded in diet I and III were similar at the starter phase. This could be attributed to varied management practises as reported by Gugolek et al. (2007) precisely handling of hygiene, as no adverse effect of feeding test diet was observed during the post-mortem examinations.

The result of the blood profile as shown in Table 4 could be attributed to efficient feed utilization in the FLBM diets. PCV, red blood cell, white blood cell and haemoglobin content of chicken blood are factors of their health status and nutrient utilization (Aderemi and Alabi,
2013). All haematological values recorded were within normal range for healthy chicken as reported by Mitruka and Rawnsley (1977). This implied that test diets did not elicit any adverse effect on the birds' health. Also, the haematological results suggest that FLBM inclusion in diets did not impair dietary iron availability such as could cause anaemia. The nutrients required for haemopoiesis were available in the feeds and properly absorbed in the gut (Adenkola et al., 2011). The result observed for total protein could probably be attributed to enhance nitrogen utilization in FLBM diets, even though all diets were isonitrogenous during formulation (Ari and Ayanwale 2012). Albumin result corroborates the report of Sokunbi and Egbunike (2000) that albumin levels tend to remain constant throughout life after reaching a maximum at about 3 weeks of age. The cholesterol value was within the normal range for healthy birds suitable for consumption without possible incidence of arteriosclerosis and coronary heart diseases (Alabi et al., 2016). The Aspartate and Alanine transaminase were within normal range for healthy birds, implying the test diets did not elicit any adverse effect on the birds. These enzymes are a mirror for overall body enzymatic and metabolic process in bird and an index of liver disease. Perhaps the probiotic effect of FLBM and interactions with host gastro intestinal microflora was partly responsible for this (Coulibaly et al., 2011).

The glucose content of those fed diet I and II were lowered compared to diet III and no adverse effect on regulation. By implication those on diet III inhibit glycolysis and thus there was adverse effect on regulation of insulin and or blood sugar. This is similar to findings of Aderemi and Alabi (2013). As revealed in Table 5, the utilisation of FLBM as alternative protein feedstuff did not suppress the physiological development of the birds. However, the significant $(P<0.05)$ decrease 
in values of dress cuts (shank, wing and breast) from control when compared to FLBM included diets could be attributed to crude protein content and its utilization in the diets. As reported by Omerovic et al. (2016), low protein diets cause differences in carcass yield, because lower protein and amino acids content (lysine, methionine and threonine) influenced weight gain and performance. The percentage of live weight for visceral organs (gizzard, liver, lungs, spleen, heart, and proventiculus) of the broilers on control and diet II were statistically similar. This suggests that boiling and fermentation process may have reduced the antinutritional factors in the locust bean as observed in the non-inflammation of the liver. However, the smaller size observed for visceral organs in birds fed diet III can be attributed to growth depression as a result of poor feed utilization due to palatability and accumulation of antinutritional factors at higher inclusion rate $(100 \%)$. As reported by Ismail et al. (2008) and Soetan and Oyewale (2009), that the presence of trypsin inhibitor in legume seeds used in animal feeds and human foods causes growth depression, and relative smaller size of organ weights to live weight in broilers fed mucuna seed meal.

\section{Conclusion and application}

It was concluded that replacement of SBM up to $50 \%$ with FLBM has a good potential for broiler production. As shown with the production performance, haematological/serum indices and carcass evaluation, the health of the chickens were not compromised with inclusion of locust beans up to $50 \%$. In view of optimum production performance, feed utilization and blood profile, $50 \%$ inclusion of locust bean to replace soybean is hereby recommended in broilers diet. Further research is recommended for increase inclusion level and application in other farm animals.

\section{CONFLICT OF INTEREST}

The authors declare that they have no conflict of interest.

\section{REFERENCES}

Adenkola. A. Y., Tughgba. T., \& Idoga, E. S. (2011). Comparative assessment of erythrocyte osmotic fragility and haematological parameters of broiler and local chicken during the hot-dry season in Makurdi. Nigerian Society of Animal Production (NSAP), Abuja, Nigeria, Pp. 117-119.

Aderemi, F., \& Alabi, O. (2013). Effect of grade levels of cassava peels fortified with moringa as a replacement to wheat bran on performance, digestibility and blood profile of broilers. Journal of Agricultural Science and Technology, 3(23), 210-215.

Alabi, D. A., Akinsulire, O. R., \& Sanyaolu, M. A. (2005).
Qualitative determination of chemical and nutritional composition of Parkia biglobosa (Jacq) Benth. African Journal of Biotechnology, 4, 812-815.

Alabi, O. M., Aderemi, F. A., Ojo, O. J, Ayoola, M. O., Oladejo, O. A., Afolabi, K. D., \& Akinoso, S. O. (2016). Antilipaemic effect of Moringa oleifera leaf powder as feed additive on serum cholesterol fractions of broiler finisher. In Proceeding of the 41st Conference of the Nigeria Society for Animal Production (NSAP), 20-24 March, 2016, Pp. 832-836.

AOAC (1990). Official Methods of Analysis. 15th ed. Association of Official Analytical Chemists, Washington, DC.

Apata, D. F. (2003). Egg production and haematological profile of laying hens fed dietary raw or processed proposis African seeds. In proceeding of the 28th Annual Conference of the Nigeria society for Animal production (NSAP), 16th-20th March 2003, Pp. 280-284.

Ari, M. M., \& Ayanwale, B. A. (2012). Nutrient retention and serum profile of broilers fed fermented African locust beans (Parkia filicooide). Asian Journal of Agricultural Research, 6(3), 129-136.

Ayanwale, B. A., \& Ari, M. M. (2002). Replacement value of Parkia filicoidea in broiler. Journal of Agricultural Technology, 1(2), 42-52.

Bridget, O. O., Olumuyiwa, S. F, Bolanie, O. A., \& Adewusi, S. A. A. (2004). Biochemical changes in Africa locust beans (Parkia biglobasa) and Melon (Citrullus vulgaris) seeds during fermentation to condiment. Pakistan Journal of Nutrition, 3(1), 140-145.

Campbell-Platt, G. (1980). African locust beans (parkia spp.) West African fermented-food Products daddawa. Ecol. Nutr., 9(3), 123-132.

Coulibaly, A., Kauakou, B., \& Chen, J. (2011). Phytic acid in cereal grains: Structure, healthy or harmful ways to reduce phytic acid in cereal grains and their effect on nutritional quality. American Journal of Plant Nutrition, and Fertilization Technology, 1(2), 1-12.

Dawodu, F. A. (2009). Physico-chemical studies on oil extraction processes from some Nigerian grown plant seeds. Journal of Environmental Agriculture and Food Chemistry, 8(2), 102-110.

Fetuga, B. L., Babatunde, G. M., \& Oyenuga, V. A. (1974). Protein quality of some unusual protein foodstuffs:Studies of African locust-bean seed (Parkia filicoidea Welw). British Journal of Nutrition, 32(3), 27-36.

Gugolek, A., Lorek M. O., Kowalska, D., \& Janiszewski, P. (2007). Production results of rabbits fed diets containing no coccidiostat during the fattening period. Journal of central European Agriculture, 8(4), 443-446.

Ismail, A., Ikram, E. H. K., \& Nazri, H. S. M. (2008). Roselle (Hibiscus sabdariffa.L) seed nutritional composition, protein quality and health benefits. Food, 2(1), 1-16.

Mitruka B. M., \& Rawnsley H. M. (1977). In: Clinical biochemical and haematological reference value in normal experimental animals. Masson publishing U.S.A, Inc.

National Research Council (NRC) (1985). Guide for the Care and Use of Laboratory Animals. Publication no. 85-23. National Academy of Sciences, Washington, DC.

Odunsi, A. A. (2003). Blend of blood and rumen digesta as replacement for fish meal and groundnut cake in layers diet. International Journal of poultry science, 2(1), 68-61.

Omerovic, I., Milosevic, B., Ciric, S., Spasic, Z., Lalic, N., \& Samardzic, S. (2016). Effect of prebiotic on performance and 
slaughter traits of broiler chickens fed lower protein diets. Journal of Livestock Science, 7(2), 168-171.

Soetan, K. O., \& Oyewale, O. E. (2009). The need for adequate processing to reduce the anti-nutritional factors in plants used as human foods and animal feeds: A review. African Journal of Food Science, 3(1), 223-232.

Sokunbi, O. A., \& Egbunike, G. N. (2000). Physiological response and organ weight of young rabbit on neem (Azadirachta indica) leaf meal based diets: haematology and serum biochemistry. Tropical Animal Production, 2(1), 81-87.
Tuffery, A. A. (1995). Laboratory Animal in: An introduction for experiments, A. A. Tuffery (ed. John Wiley and Son Ltd. England).

Tuleun, C. D., Adenkola, A. Y., \& Oluremi, O. I. A. (2009). Performance of characteristics and haematological variables of broilers chickens fed diets containing mucuna seed meal. Tropical Veterinary Journal, 25(2), 74-81. 